\title{
Borderline Serous Cystadenoma
}

National Cancer Institute

\section{Source}

National Cancer Institute. Borderline Serous Cystadenoma. NCI Thesaurus. Code C4177.

A serous cystic glandular epithelial neoplasm of low malignant potential. It is

characterized by the presence of atypical or malignant glandular epithelial cells with an absence of stromal invasion. 